\title{
The Thematic Study of Time in Yeats's Mystical Man
}

\author{
Shenghua Yang ${ }^{1}$ \\ ${ }^{1}$ School of Foreign Languages, China West Normal University, Nanchong, China \\ Correspondence: Shenghua Yang, School of Foreign Languages, China West Normal University, Nanchong, \\ Sichuan, China. Tel: 86-151-8178-9712. E-mail: yangshenghua2014@sina.com
}

\author{
Received: September 19, 2014 Accepted: October 10, 2014 Online Published: November 25, 2014 \\ doi:10.5539/ells.v4n4p72 URL: http://dx.doi.org/10.5539/ells.v4n4p72
}

\begin{abstract}
William Butler Yeats is the most widely admired and intensively studied poet of the twentieth century. Very few of the critics have noticed the theme of time in his poetry concerning the mystical man. As a matter of fact, the theme of time is a thread to grasp Yeats's mystical man in his poetry as a whole. Time's destructive power on man associated with mystical theme has been shown clearly in Yeats's poetry. As the useful means to combat time's deadly workings, love for his beloved and love for idealized Ireland transcend the temporal limitation and achieve eternity. Memory as the continuation of love is another suggestive way to defeat time. Art has also the great power to withstand time's destruction and brings eternity to man. Three distinctive features of Yeats's poetry - a form of literature, a form of philosophy and a belief in nationality are hammered into the unity of the time theme in his mystical man.
\end{abstract}

Keywords: theme of time, mystical man, Yeats

\section{Introduction}

William Butler Yeats (1865-1939), as the greatest poet of Ireland and the acknowledged leader of Irish Renaissance, ranks among the most widely admired and intensively studied poet of the twentieth century. Taking a panoramic view of Yeats studies, Yeats's works have been treated as an integrated whole and the thematic studies have taken a center stage. Themes raised in his early works are still present in the later works, developed and explored or revisited from the changing perspectives of age and experience. Creating unity, mythologies, masks, magic, symbolism, Ireland, love, history and prophecy, death and old age are those themes which have been focused on. However, the past thematic studies of Yeats's poetry have almost made no inquires into the motif of time, which is one of the controlling themes and has taken important position in the thematic studies of Yeats's poetry.

It is noteworthy that man is the only being on earth, who has the awareness of time, "a being for whom the problem of time is not merely one of theory but one which is supremely and intimately related to the conduct of his life"(Fraser, 1966, p. 32). Time gives man the sense of his limitation. Man can determine the order and content of his time, even interpret concrete definition of time under some certain circumstance through himself. The flowing time is always confronting man with its destructive power, and in turn, man becomes more effective in the common struggle for existence when he faces the challenge of time. Time, as a theme of great importance, is a thread to grasp Yeats's mystical man in his poetry as a whole, yet it has not been touched upon in detail. This article attempts to point out this neglect and approaches love of man, memory of man and art of man in terms of the interconnected manifestations of time.

\section{Discussion}

\subsection{Time and Love of Man}

Yeats is intensely aware of man in history and soul in eternity. Time's powerful destruction on man is depicted well in Yeats's various poems such as "The Lamentation of the Old Pensioner", "To Ireland in the Coming Times", "The Lover Pleads with his Friend for Old Friends", "The Old Men Admiring Themselves in the Water" and "The Tower".

Yeats expresses the sense of transience of life and reveals the destructive force of time through an old pensioner's lamentation: "Ere Time transfigured me". Yeats's selection of the verb "transfigure" is significant, for the word not only means the change of appearance, but also denotes the exaltation and glorification resulting 
from such change. Its use here indicates that the speaker has been devastated and reduced by time. The poet gives further indications of the decay that time brings to man in "The Tower". As time flies, the speaker becomes weaker and weaker, who has only "the wreck of body, slow decay of blood, testy delirium or dull decrepitude" (Yeats, 2008, p. 169).

This profound thought of time's destructive power is reinforced in "To Ireland in the Coming Times". The strong power of time controls man from birth to death in this poem. Besides, man's love and singing, and "all benighted things" are destined by time's destruction, and pass to somewhere and decay unavoidably. The same idea can also be found in "The Lover Pleads with His Friend for Old Friends":

Time's bitter flood will rise

Your beauty perish and be lost

For all eyes but these eyes. (p. 58)

These lines are prophetic. The speaker claims his prophecy that time's destruction cannot be prevented, and the beauty of his beloved will perish as time flows. Apart from the beauty of his beloved, all beautiful things will drift away when time's flood rises and takes away everything in "The Old Men Admiring Themselves in the Water".

Yeats has revealed profoundly time's destructive effect on man in the above poems; meanwhile the poet has his special explorations of the relationship between man's sexual love and time's circular movement in his famous poem "Leda and Swan". Yeast's fancy in this poem is based upon the Greek myth of Zeus, taking the form of a swan and impregnating the mortal Leda, daughter of Tyndareus, king of Sparta. She bore the twins Castor, symbol of war, and Pollux and Helen, symbol of sexual love. In the first two stanzas of this poem, the sexual love between the body of Leda and swan is depicted circumstantially and implies some significant events related to time's destruction. The eggs of Leda, as a result of the rape, cause the fall of Troy. This link between sexual love and time's destruction is convinced in the quotes of Todhunter's Helena in Troas:

O pitiless mischief! Thee no woman bore

Wooed by the billing of the amorous swan.

Yea, Leda bore thee not but Nemesis

To be the doom of Troy and Priam's house. (Jeffares, 1984, p. 248)

Based upon this link, Yeats gives his prophecy boldly that the old civilization is at end and a new civilization will rise as a result of sexual love and war. Thus, time's destruction and its circular movement are closely linked with man's body and sexual love.

How to defy time in human world? Unlike animals, man possesses his special ways to challenge time of his own accord. The ancient Egyptian reaction to time provides the earliest example of a certain pattern of response to the challenge of time. Man's awareness of time has made him conscious of his own mortality, causing him to form a sense of insecurity that the passage of time brings change that might be unpleasant and would ultimately bring death to him. According to Egyptian Pyramid Texts, "the anticipation of death inspired the desire to achieve some form of security beyond the effacing flux of time". (Fraser, 1966, p. 145) According to Pythagorean Cosmology, "time is a cosmos composed of days, seasons, and years". (Heninger, 1974, p. 222) Man prosecutes the pattern of time by completing the four ages of his life: "Childhood takes up Twenty years, Youth Twenty, Manhood Twenty, and Old age Twenty. These Ages compared to the Seasons of the Year, Childhood to the Spring, Youth to Summer, Manhood to Autumn, Old-age to Winter." (Heninger, 1974, p. 224) In order to challenge time's destruction, two lovers can imitate the cosmic pattern of completeness in the act of love. Thus, love is an effective way to achieve the timelessness of eternity, and the undifferentiated inclusiveness of infinity. In such a way, man transcends his temporal limitation and achieves eternity. From the standpoint of Neo-Platonism, "beauty is the divine quality and the manifestation and precipitating force that stirs desire for itself in all things and which expresses itself as love". (Ficino, 2008, p. 58) Love, as "the knot and the binding of the universe" can unite the lower world with higher world. Man will ultimately discover and recover his divine nature through a bond of active love. The final stage in the Platonic ascents that love gives the soul greater happiness still. "For just as from the particular beauty of single body it guides the soul to the universal beauty of all bodies, so in the last stage of perfection, it guides the soul from the particular intellect to the universal intellect. And from there, aflame with the sacred fire or true divine love, the soul flies to unite itself with the angelic nature, the eternal world." (Castiglione, 1976, p. 340) These philosophical thoughts have laid profound foundations for Yeats's creative views toward two kinds of love to defy time: love for his beloved and love for 
idealized Ireland.

It is well-known that Yeats has spent his lifetime loving a lady named Maud Gonne with remarkable beauty and great passion for the independence of Ireland. Yeats fell in love with Maud Gonne at his first sight in 1889. During so many years of proposing to Maud Gonne, Yeats wrote many love poems and implied that his love for her could transcend time's limitation, promote soul to the eternal world and achieve immortality. In "Ephemera" the speaker gives comfort to his beloved that although their love is waning under the influence of the flowing time, they still have other loves. Eternity still awaits them because love is united with their souls and enhances them to the world of immortality. The same idea is stressed in "The Man Who Dreamed of Fairyland" and "Solomon to Sheba". The two poems reveal the poet's adoration of love's inconceivable power to challenge time. Time is powerless before "a lover's vows".

Yeats becomes more rational after his marriage and enhances the love for his wife to a higher level that is above that of Maud Gonne in "Solomon to Shebar". In the last stanza of this poem, Solomon, king of Hebrews, symbolizes Yeats. Shebar is the symbol of Mrs Yeats. Yeats wrote about the theme of love in his 1910 Diary: "It seems to me that true love is a discipline, and it needs so much wisdom that the love of Solomon and Sheba must have lasted, for all the silence of the scriptures. ...Love also creates the Mask." (Yeats, 1965, p. 464) So the caution here is that Yeats has brought love into his mystical system. He believes that love creates the Mask, one of its indispensable theories, and asseverates that only love has the power to "make the world a narrow pound".

The disordered reality of Ireland in Yeats's poetry is doomed to be destroyed by time's destructive power just as he predicts in "September 1913":

Romantic Ireland's dead and gone,

It's with O'Leary in the grave. (p. 87)

The poet shows his disappointment of the doctrines and actions of the rational nationalists and gives his reaction to the Easter Rising in Dublin: "All changed, changed utterly: A terrible beauty is born."(p. 152) As an Irish poet, Yeats also intentionally considers his love for the idealized Ireland as an effective way to defy time. He recalls and praises beautiful sceneries and the ancient and mythological past of Ireland. The idealized Ireland, the ancient Ireland full of sceneries and Irish legends, achieves eternity in Yeats's poetry. In "To Ireland in the Coming Years", the poet expresses his love for the idealized Ireland, the ancient and mystical beauty that makes "Ireland's heart begin to beat". His deep love for his motherland emerges in the lines that "while still I may, I write for you the love I lived, the dream I knew." (p. 41) The poet hopes that his poems, expressing his love for the idealized Ireland, will make the eternal beauty in the coming years. This deep emotion is distinctively shown in the following lines from "Under Saturn":

I am thinking of a child's vow sworn in vain

Never to leave that valley his fathers called their home. (p. 151)

\subsection{Time and Memory of Man}

As the above has discussed, love is Yeats's positive ways to defy time. There are several ways for one to love another or to perpetuate him or her. Keeping the loved in memory is one effective way. It is necessary to explore memory as one of Yeats's positive ways to defy time because memory itself is not only the continuation of love, one of significant means to challenge time, but also the promoted state of dream, which defies time in its special way. The dream is one of the genres within which remembrance may occur. "The hours that hold the figure and the form have run their course within the hour of dream."(Miller, 2009, p. 24) The dream is the instrument and medium of memory. As the scholar argues, "The dream appears not as the trivial and confused double of sober waking life, but as the more powerful of the two states: the grip of natural history, of myth, of death upon human history, whether in its biographical or its collective form. The dream is seen as a mode of memory, the chance to recover things forgotten in the progress of life, and an index of mortality, a measure of the distance of the adult sleeper from the dreamer who revives the happiness of childhood. Memory may be fatally seductive, the siren song of life long gone, and thus requires careful safeguards against falling under its sway.” (Miller, 2009, p. 24)

Yeats promotes dream's effect to defy time to a higher level upon which memory plays an indispensable role to defeat time. This deep thought can be found in "Broken Dreams". In this poem, the speaker first manifests time's destructive power on his beloved: "There is grey in your hair". However, beauty can exist in vague memories, from which rebirth rises upon death:

Your beauty can but leave among us

Vague memories, nothing but memories. 
...

Vague memories, nothing but memories,

But in the grave all, all, shall be renewed. (p. 128)

Memory itself is chronologically organized. Our intuitive conception of memory takes for granted that it is infused with chronology. More to the point, "memory delivers a peculiar direct, non-inferential form of knowledge about the past". (Hoerl, 2001, p. 22) That is to say, memory itself is specially regarded as a genuine source of knowledge. Yeats's creative thought of memory's function is deep-rooted in Platonism. The poet himself gives his note on Plato and Plotinus when he tries to assimilate the essence of the two great philosophers. Soul is the origin of the world and an eternal being. In Yeats's supernatural order, spirit, which is both one and many, is the source and centre of all things. "Contemplating a wrecked world, he(Yeats) does not learn to renounce life and passion, but detaches them from time, declares that they belong to eternity and will be rebuilt again and again in new forms." (Stock, 1961, p. 189) Yeats has promoted the state of soul and puts forward the conception of The Great Spirit or The Great Memory in the famous poem "The Second Coming":

The Second Coming! Hardly are those words out

When a vast image out of Spiritus Mundi

Troubles my sight:... (p. 159)

These selected lines focus on the central issue Spiritus Mundi, which is a general storehouse of images which have ceased to be a property of any personality or spirit. For Yeats, man's spirit can communicate and build up The Great Spirit. In doing so, man's memory is flowing and forms The Great Memory. The great memory is a deeper source than conscious and subconscious memory. The great memory enables human soul to make the past memories be a new vision of essential being because it creates dream images and thereby renews its state of being. Although man's body is destined to die due to the influence of time's destruction, man's soul can achieve eternity through the special function of The Great Memory or The Great Spirit so as to fulfill the goal to defeat time. This creative thought can be found in "A Meditation in Time of War":

I knew that One is animate,

Mankind inanimate phantasy. (p. 161)

As Plotinus puts it that One generates reason, which results in soul or spirit, and finally, matter. Based upon some kind of essence of Platonism, Yeats has delivered his ingenious thought of One in this poem that when time comes to an end, the soul puts on the spiritual body or the luminous body, and contemplates all the events of its memory and every possible impulse in an eternal possession of itself in one single moment. He declares that eternity is the possession of one's self, as in a single moment.

Yeats's promotion of the strong power of memory is also reflected in other poems such as "The Tower" and "The Broken Dreams". In "The Tower" Yeats depicts clearly that images of men-at-arms, stored in the Great Memory, come out of the limitation of time. More to point, the poet combines memory with other effective ways to defy time such as dream, art, imagination and love, and creates Translunar Paradise, which is "beyond the moon, out of time" (Jeffares, 1984, p. 223). Apparently, eternity is achieved after death when the speaker prepares peace with memory and other useful means to defy time.

\subsection{Time and Art of Man}

A host of symbols of time exist in the imagination of poets and artists. For instance, Shakespeare "has implored, challenged, berated and conquered time in more than a dozen sonnets" (Panofsky, 1939, p. 92), whose "wasteful time", "devouring time" and "time's fickle glass" are the endurable and marvelous images in English literary convention. Time's two basic images - the Greek Kairos and the Iranian Aion together with the emblems of decrepitude and decay - the hourglass, the scythe or sickle and the crutches embody boundless power and plentitude in a great many creative works of the poets and artists. Time brings corrosion and decay, inexorable and irreversible aging and death to human minds. Poets and artists have depicted a lot on man's efforts to challenge time, to cast off his chronological chains and to resist the teeth of time. For them, art is still an effective way to defy time.

Absorbing the valuable nutrition in English literary tradition, Yeats manifests that his words in his poetry, a kind of art, can withstand time's destruction and challenge time with its eternal fame. This profound thought is apparent in "The Song of the Happy Shepherd". Time has shown its irresistible power in this poem. Many things have changed such as the death of "the woods of Arcady" and "antique joy". Confronting the powerful time, the poet still insists that "words alone are certain good". That is to say, only words can avoid time's destruction and 
brings eternity. As the poet's good wish in "To be Carved on a Stone at Thoor Ballylee" indicates:

And may these characters remain

When all is ruin once again. (p. 162)

As a poet and prophet, Yeats predicts that the Doomsday is coming naturally and only words carved on a stone can remain.

Apart from words in poetry, Yeats suggests that sword and lapis lazuli, as the important forms of art in his poetry also embody characters of eternity. In Yeats's poetry, art is used as an effective weapon to defeat time. As a special form of art, sword is first depicted in "My Table". From this poem, we can see that the most significant thing on the table is "a changeless sword", which is a priceless gift from Sato, a Japanese diplomat. It is obvious that the changeless sword has been endurable through 500 years and is valued as the effective weapon to defeat time. The same function of the sword can be found in Yeats's another poem "A Dialogue of Self and Soul". Yeats has made his Japanese sword and its silk covering his symbol of life, as he says in his letter to Olivia Shakespeare. The sword upon the poet's knees is "still razor-keen" and "like a looking-glass". In other words, it is "unspotted" by time's destructive force throughout "the centuries". Therefore, life, as well as its symbol — sword, cannot be spotted by time's destruction and achieves eternity with the aid of art.

Yeats emphasizes art's strong force against time's destruction in his famous poem "Lapsi Lazuli". The poet describes the lapis lazuli as a kind of art work. The poet has found the eternal theme in the art work and writes this poem with his inspiration of art's greatness. In this poem, time moves forward and causes all things to fall and be built again. Images carved in lapsi lazuli such as the "long-legged bird", the "musical instrument" and lapsi lazuli itself stand for longevity, and defeat time's destruction with art's special function.

The most profound thought of art's great power to withstand time's destruction lies in Yeats's Byzantium poems. The poet has a profound fascination for Byzantium, an ancient city on the site of present day Istanbul. Yeats's use of Byzantine and Byzantium in the following poems: "The Old Age of Queen Maeve", "Sailing to Byzantium" and "Byzantium". It is necessary to point out that "Sailing to Byzantium" and "Byzantium" are the most obvious illustrations of art's indispensable position. When Yeats wrote "Sailing to Byzantium", he was an aged man, who had received international reputation. Therefore, the internal structure, artistic creation and the symbolic meaning of this poem are more precise and delicate, reflecting the essence of Yeats's philosophical thought of time.

It is difficult for the youth to have Byzantium's state of mind, for they are often addicted to sensual enjoyment and too young to understand the essence of life, although they have strong body full of vigor. It is also not easy for the old to reach Byzantium, for they have decayed both in physics and in spirit. Having experienced spiritual torment of Last Days, Yeats explores recreation and achieving eternity in "Sailing to Byzantium". The time theme concerning recreation and eternity is shown clearly in the following:

The first stanza is rich in the conception of reproduction and recreation. "The young in one another's arms"(p. 163), the salmons swimming in the fall and the mackerels crowded in the sea stand for reproduction and recreation of life, and predict what is begotten and what is born. Youth is the golden period of life, which is filled with vitality and vigor. In the first three lines, the young just have sensual enjoyment and this sort of vitality cannot last forever. Yeats uses "birds in the trees - those dying generations - at their song" to reveal his own meditation on life and death.

"An aged man" appears in the second stanza, who speaks out the true feelings of the poet himself, for "the protagonist of the poem is not Yeats but may be described as a symbol of Yeats and of the artist and of man." (Ellmann, 1964, p. 257) "A tattered coat", a dispensable symbol of this stanza symbolizes that the speaker has went through quite a lot joys and pains. The body of the speaker has been devastated; however, time's deadly workings have illuminated his being and granted him heightened vision. "If we live beyond death, then there must be some place or quality of life to which we come that reflects the quality of our spiritual character before death."(Neville, 1993, p. 204)Thus, the speaker decides to sail the sea and "comes to the holy city of Byzantium". Moreover, the speaker in this stanza can be regarded as a transformed Noah. "Sailing" is used as part of the title and signifies that the protagonist of the poem, the transformed Noah, confronting the chaotic world, sails the sea and reaches the holy city of Byzantium. Noah in Bible, guided by the Lord God, built an ark for the survival of the chosen creatures and the existence of the faithful belief of God's magnificent power. Facing the destruction of the flood, Noah's ark preserved his family, the chosen animals, and most importantly, some immortal and eternal things. In this poem, the speaker, the symbol of Yeats and of the artist, guided by the Lord God of Art, has built an ark of art for the survival of the chosen creatures and for the faithful belief of the eternal art. 
The speaker, who has got inspiration from some paintings in the third stanza, provides an effective way to achieve salvation from the chaos resulting from the coming of the Last Days. He hopes that he would be gathered into the artifice of eternity after death so as to defeat time:

Once out of nature I shall never take

My bodily form from any natural thing,

But such a form as Grecian goldsmiths make

Of hammered gold and gold enameling

To keep a drowsy Emperor awake;

Or set upon a golden bough to sing

To lords and ladies of Byzantium

Of what is past, or passing, or to come. (p. 164)

The image of golden bird in the fourth stanza symbolizes not only recreation and reproduction but also the eternity incarnated in art. Being tired of the chaos of the reality, which Yeats describes as the bad situation during the Last Days, Yeats chooses to leave from the world of chaos to his ideal place. In this poem, the poet expresses the idea that he is willing to be a golden bird in Byzantium, setting upon a golden bough to sing. Yeats builds his own bodily form as a golden bird, symbolizing the reproduction and recreation of his body, his soul and his poetic art. Although his body is doomed to vanish, his spirit and poetic art can be eternal in the form of golden bird. In this sense, art's unimaginable power, symbolized by golden bird singing in the golden bough, redeems the swiftness of life and makes man achieves eternity in the course of defeating time.

The poem "Byzantium" also explores Yeats's systematic account of the "death-in-life and life-in-death", and characterizes the perfect being of art and its great power in defeating time's destruction. The image of the unity of flesh and spirit challenges time's restraint by the dolphin's escort of the dead through the sea to paradise. In Byzantium poems, the spiritual life and the creation of art merge as one. Time's power is so weak that it cannot bring any forms of destruction to the perfect state.

\section{Conclusion}

Time has become one of literature's primary themes in the twentieth century. Although Yeats was not alone in thematically ordering his poetry by combining the force of time and the pursuit for eternity and ways available to defy time, he was far more involved in this process than most of his contemporaries. The obsession with time makes the mystical man of Yeats's poetry appear so outstanding in the stage of English and Irish literature. Fact and symbol, world and soul, history and eternity, are woven together in Yeats's mystical man with the guide of the time theme. Time's destructive power on man associated with mystical theme has been shown clearly in Yeats's poetry. As for the useful means to combat time's deadly workings, love for his beloved and love for idealized Ireland transcend the temporal limitation and achieve eternity. Moreover, memory, the continuation of love, is a suggestive way to defeat time. Although man's body is destined to die due to time's destruction, man's soul can achieve eternity through the special function of The Great Memory or The Great Spirit so as to fulfill the goal to defeat time. In addition, art has the great power to withstand time's destruction and brings eternity to man. Three distinctive features of Yeats's poetry - a form of literature, a form of philosophy and a belief in nationality are hammered into the unity of the time theme in his mystical man.

\section{References}

Castiglione, B. (1976). The Book of the Courtier. Baltimore: Penguin Books.

Ellmann, R. (1964). The Identity of Yeats. London: Faber.

Ficino, M. (2008). Commentary on Plato's Symposium. Cambridge: Harvard University Press.

Fraser, J. T. (Ed.). (1966). The Voices of Time. New York: George Braziller, Inc.

Heninger, S. K. Jr. (1974). Touches of Sweet Harmony: Pythagorean Cosmology and Renaissance Poetics. U.S.A.: Kingsport Press.

Hoerl, C., \& McCormack, T. (Eds.). (2001). Time and Memory: Issues in Philosophy and Psychology. New York: Oxford University Press.

Jeffares, A. N. (1984). A New Commentary on the Poems of W. B. Yeats. London: The Macmillan Press Ltd.

Miller, T. (2009). Time-Images: Alternative Temporalities in Twentieth-Century Theory, Literature and Art. 
Newcastle: Cambridge Scholars Publishing.

Neville, R. C. (1993). Eternity and Time's Flow. New York: State University of New York Press.

Panofsky, E. (1939). Studies in Iconology. New York: Oxford University Press.

Stock, A. G. (1961). W. B. Yeats: His Poetry and Thought. London: Cambridge University Press.

Yeats, W. B. (1965). The Autobiography of William Butler Yeats. New York: Macmillan Publishing Company.

Yeats, W. B. (2008). The Collected Poems of W. B. Yeats. Hertfordshire: Wordsworth Edition Limited.

\section{Copyrights}

Copyright for this article is retained by the author(s), with first publication rights granted to the journal.

This is an open-access article distributed under the terms and conditions of the Creative Commons Attribution license (http://creativecommons.org/licenses/by/3.0/). 